\section{Native Medical Practitioners in the South Seas}

THE Government of Fiji recognized many years ago the need for a medical service for the native population, but realized that the employment of European doctors on a large scale was impracticable on account of cost, and that practitioners of their own race would be best suited to attend to the needs of the natives. The Government therefore established the Native School of Medicine at Suva for the benefit of Fijians, and for many years its 'graduates' did excellent work. A few years ago, the Rockefeller Foundation commenced investigations upon the problems of disease and of depopulation in these islands, and was so impressed with the success of this Native School that it offered to co-operate with the Fijian Government, and suggested the training of natives from eight groups of islands in the School at Suva. The Government agreed to work in conjunction with the Foundation, and the School was then reorganized and reconstituted in its present form. The School is residential, and is attached to the Suva Memorial Hospital. Its direction is in European hands, the students are under reasonable discipline, and the cost of maintenance is small-something less than $£ 3,000$ a year-which is contributed in various ways.

SIR JAMEs BARReTT, Vice-Chancellor of the University of Melbourne, gives an account of the activities of the School in an article in the Morning Post of August 7. The students are mostly Polynesians, and must pass a matriculation examination before admission, based upon the Now Zealand proficiency examination, which ensures a good knowledge of English. The first year of the present four-years' course is devoted to elementary basic science, and the remaining three years provide the student with a sound, practical medical training in the Suva Hospital. After graduation, the practitioners return to their own islands as health or medical officers among their own people. The initial salary of a graduate is $£ 60$ a year, rising to a maximum of $£ 150$, which suffices for local requirements. If no European doctor is available, as is often the case, the native practitioner may attend to the medical requirements of Europeans. At present, eighty-four practitioners are at work, distributed over Fiji, Samoa, Tonga, the Cook Islands, Gilbert and Ellice Islands, Solomon Islands, and New Hebrides; of these, Fiji takes fifty-six. In addition, native nurses have been trained in large numbers; the Suva Hospital is staffed by twenty European and twenty Fijian nurses, and there are forty-seven obstetric nurses in Fiji alone. Sir James Barrett endorses the very favourable opinion on the efficiency of the School and of the practitioners it has trained expressed by Profs. Wright and Buckmaster, who, having visited Australia and New Zealand on behalf of the Royal College of Surgeons of England, passed through Suva on their return journey. Sir James envisages the adoption of some such system to meet the medical needs of the natives in other parts of the British Empire, referring to the existence of somewhat similar schools already founded in West Africa and Uganda.

\section{The Radcliffe Observatory in South Africa}

The 'turn-over' article in The Times of August 7 by Mr. H. E. Wood, the Union Astronomer, deals with astronomy in South Africa in general, and refers in particular to the forthcoming re-establishment of the Radcliffe Observatory at Pretoria. The history of astronomy in South Africa begins in 1685, when Father Tachard called at the Cape on his way to Siam and determined the longitude by observations of Jupiter's satellites. During the next century, two expeditions visited the Cape, and 1820 saw the foundation of the Royal Observatory, which has made such notable contributions to our knowledge of the southern stars. In 1834 Sir John Herschel landed there and made his famous catalogues of nebulæ and double stars. There are now four other observatories in South Africa: the Union Observatory and the southern station of Yale University Observatory at Johannesburg, and those of Harvard and Michigan at Bloemfontein. The Radcliffe Observatory, for more than a hundred and sixty years at Oxford, will, it is hoped, have started its new life at Pretoria within the next two years. Good progress is being made with the construction of its 74-inch reflector by Sir Howard Grubb, Parsons and Co. This will differ in several respects from its sister telescope at Toronto, as it will have, in addition to facilities for observation at the Newtonian and Cassegrain focuses, an arrangement for sending the beam of light down the polar axis to a fixed spectrograph, and it will be driven by a synchronous motor, the frequency of the alternating current being controlled by a tuning fork. The disk of Pyrex glass for the large mirror has been cast by the Corning Glass Co. and is now being annealed. The five secondary mirrors will be of fused silica, and the disks for these are being made by the Thermal Syndicate, Ltd.

\section{Archæological Excavations in Britain}

WITH the coming of university and school vacations, numbers of voluntary workers are released for archæological investigations in the field. Since July, excavations have been resumed or initiated on many sites in Britain. The scheme of training in field work through voluntary assistance organized by Dr. R. E. Mortimer and the late Mrs. Wheeler is again in being, this year on an extended scale. Nearly a hundred students drawn from universities in the British Isles, Australia, India, Canada, the United States and China are at work on the continued excavation of Maiden Castle, near Dorchester, under the direction of Dr. Wheeler and Col. C. D. Drew. Although the season has only just opened, some important results already have emerged. On the hill-top in the neighbourhood of the temple of the Roman period discovered in 1934, according to a report in The Times of August 14, further stone age habitations, with stone implements and pottery, have been discovered. A series of pits has been uncovered, in which were pottery and animal bones, including those of large oxen of a type now extinct. The neolithic site underlying the fortifications is also being explored. Extensive areas containing stone implements and pottery 
have been opened up; and a stone age trench now being examined is found to be covered with a wellmarked line of turf underlying the later prehistoric rampart. It contains large masses of material of the stone and early bronze ages, while on top of the trench numerous sherds of elaborately decorated Early Bronze Age pottery are being identified.

Excavations have also been resumed on behalf of the Ipswich Museum under the direction of the curator, Mr. Guy Maynard, on the Stanton Chair Farm Roman site between Ixworth and Stanton in Suffolk, where investigations were initiated last autumn as a result of the observation of Roman potsherds and tile fragments in a field. Although it is known that the area of the site is at least two hundred feet across, operations at present are confined to a narrow strip, as the ground is under crops. Work, accordingly, has been concentrated on clearing the remains of a bath-house, of which the hypocaust pillars are well preserved, and a drain from the cement floor of an adjacent room still remains. Two levels of flooring and coins of Marcus Aurelius (A.D. 161186) and Eugenius (A.D. 393) suggest a prolonged, but interrupted occupation. Six weeks of excavation at Castle Dore, an Iron Age hill-fort, near Fowey, in Cornwall, under the direction of Mr. Ralegh Radford, with the unemployed for labour, has confirmed previous conclusions as to its character. It was evidently a strong point commanding the ancient prehistoric road and trade route across the peninsula. It is now considered beyond reasonable doubt that this was, as has been suggested, the palace of the King Mark of Arthurian legend. Students of the University of Liverpool excavating, also with the assistance of local unemployed, on Eddisbury Hill, Cheshire, have brought to light traces of an ancient fortress in the form of walls of local sandstone, five to six feet in height, in an excellent state of preservation.

\section{Ultra-short Wave Radio Communication}

THE practical application of ultra-short waves to radio communication made a step forward on June 11, when R.C.A. Communications Inc. gave a public demonstration of their new circuit connecting New York with Philadelphia. A brief illustrated description of this demonstration is.given in the June issue of Communication and Broadcast Engineering (U.S.A.). The circuit operates over a distance of about 91 miles with the aid of two automatic relay stations situated between the terminal stations at New York and Philadelphia, the longest individual link being 36 miles. A two-way service is provided, and the six wave-lengths required are in the neighbourhood of three metres; the stations are equipped for the transmission of drawings, typescript and other visual material in facsimile, with simultaneous operation of typewriter and telegraph channels. The article referred to above includes a schematic diagram of the circuit which is reproduced from one actually transmitted to New York by the facsimile circuit. The transmitters make use of resonant line circuits in order to secure frequency stability, while the receivers incorporate the new acorn tubes specially produced for ultra-short wave purposes.

Av interesting feature of the new installation is the method by which the unattended relay stations may be turned on or off from either of the terminal stations. The receivers at each of the four stations are always alive and available for reception from their corresponding transmitters. When it is desired to make the circuit ready for traffic, New York or Philadelphia sends out a tone modulation on its carrier wave. This tone is accepted by the receiver at the first relay station, and is caused to start up its own transmitter, which then passes the tone modulation on to the second relay station. The operation is repeated here and also at the other terminal station, where the tone is re-transmitted back through the relay stations on the return circuit. Thus when the tone signal is received back at the terminal station from which it originated, it is known that all six transmitters are in operation and the radio circuit is ready to pass traffic. When the circuit is no longer required, the tone is removed and the transmitters are automatically switched off, one by one, in the same sequence.

\section{League of Nations Reform}

IN a pamphlet entitled "Anarchy or Peace", Lord Davies discusses the dangers of the present situation in Europe and the possibilities of avoiding the outbreak of an even more disastrous European war (London: The New Commonwealth. 9d.). Referring to the defects of the League of Nations as demonstrated by recent events, Lord Davies asserts that these were due to the absence of an equity tribunal and international police force, and more particularly to the lack of cohesion and determination on the part of States members of the League. Accordingly, he heavily discounts a good many of the proposals to reform the League as designed rather to deprive the League of the very functions which would enable it to secure the peace of the world if its machinery were honestly and whole-heartedly used. Proposals to substitute a series of regional pacts are only too certain to plunge us back in the pre-War system with its inevitable outcome. Lord Davies argues that the only solution of our present dangerous situation lies first in the creation of peaceful procedure for the settlement of all disputes and the revision of treaties. For this purpose, in default of a more satisfactory solution, an equity tribunal holds the field. Secondly, an international police force is required, and he urges once more the equipment of a European air police force under the control and direction of a neutral authority, a reconstituted League. This force must be superior in numbers and equipment to the national air force of any European State which refuses to join in the guarantee. Only a scheme on these lines will suffice to restore the confidence of the smaller powers in the integrity and good faith of the great powers, and endow the League with the superiority of force essential for the establishment of the rule of law. 